\title{
INTRA-HOUSEHOLD GENDER-BIAS IN CHILD EDUCATIONAL SPENDING IN RURAL ETHIOPIA: PANEL EVIDENCE ${ }^{1}$
}

\author{
Andinet Delelegn ${ }^{2}$
}

\begin{abstract}
Qualitative and quantitative evidence reveals pervasive gender discrimination in many social and economic aspects in least developing countries, including Ethiopia. Investment in child schooling is an important dimension of this discrimination, which has a lasting consequence on both the child and the country's economic development as a whole. The main objective of this study is to uncover if there is any intrahousehold gender-bias in the decision to enrollment and allocation of resources to child education. Using a panel data set from Ethiopian Rural Household Survey (ERHS), spanning from 1994-2004, we applied a panel hurdle models consisting of random effects probit for the initial decision in enrollment and conditional linear autoregressive model for the proportion spent. We found statistically significant gender-bias during the initial decision to enrollment against girls, especially those corresponding to secondary school cycle. Since the bias occurs inside the household, public investments should not only focus on facilitating access to school but also work towards altering the demand side as parents have differential preference towards siblings' education. Policies that increase returns to girl's education, increasing intrahousehold productivity, legislations that prohibit early marriage, etc. could mitigate the observed level of intra-household gender-bias against girls aged 15-19 years.
\end{abstract}

JEL Classification: D00; D13; I00; 120

Keywords: Gender-bias, Hurdle models, children's education, rural, Ethiopia.

\footnotetext{
${ }^{1}$ The final version of this articles was submitted in June 2008.

${ }^{2}$ Ethiopian Economic Association//Ethiopian Economic Policy Research Institute Poverty and Human Resources Division
} 


\section{Introduction}

Education is broadly considered as critical in income generation, in altering inequality and it is an essential part of personal welfare (Behrman, 1997). Since the works of Mincer (1974) in labor economics, voluminous works regularly confirm that a return to schooling is associated with higher individual earnings. The return to schooling is also much more significant in economies of considerable liberalization and macro stabilization that have become increasingly integrated into international market (Behrman, 1997). In developing countries, education is also crucial in augmenting earnings and improving survival strategies (Dercon and Krishnan, 1999).

Evidence from developing economics shows the importance of investing in female education, which reduces fertility rate (Cochrane, 1979), ameliorates children's health conditions (Thomas 1990, 1994, Subbarao and Raney, 1995), and changes the patterns of households' consumption with a reduction in income share for adult goods (Rosenzweig and Wolpin, 1988; Haddad and Hodinott, 1995). Nevertheless, still there are significant gender differentials in human capital status. For instance, net enrollment ratio in the year $2000-2005$ is $70 \%$ and $66 \%$ for primary school while it is $30 \%$ and $24 \%$ for secondary school in Sub-Saharan Africa, for male and female children, respectively (UNICEF, 2007).

For parents in poor economies, children are both consumption good as they gives utility, a production good as they help in productive and domestic activities and insurance good for parents during old age (Dasgupta, 1993). However, a growing concern for many has been the possibility of increasing inequality as parents have different preferences in allocation of resources to boys and girls schooling. This differential treatment may arise from difference in returns of sibling human capital investment (Rosenzweig and Schultz, 1982; Berhman, 1982) because most of women's work is limited within the family for household survival. Women not only have few opportunities to find jobs because of the low level of economic development and the consequent low labor demand but also because of discrimination in the labor market and wage differential. Parents may prefer a particular type of child irrespective of investment (Berhman, 1982). Variation in the costs of investment among siblings also induces differential treatment of children schooling (Strauss and Thomas, 1995).

Following recent development in intra-household models and availability of data, the literature has attempted to scrutinize individual-level outcomes due to differential treatment by gender in different countries. For instance, Rosenzweig and Schultz (1982) explained the excess female mortality in India to be associated with low 
female labor market participation in terms of the reinforcement of productivity difference. Afridi (2005) from India has found that mothers' autonomy has a significant impact on reducing the gap in educational attainment of girls and boys. Hazarika (2000) for Pakistan, Quisumbing and Maluccio (2000) for Bangladesh, Indonesia, Ethiopia and South Africa are also among the most notable empirical studies.

In the literature there are two commonly applied techniques to detect gender bias in the intra-household resource allocation. The first method, based on availability of individual level data, is the direct comparison of expenditure on males and females. The second methodology is to use the Engel curve approach in situations where reliable data is only available at the household level. In most cases, the former method can not be practical due to absence of such disaggregated survey data. The Engle curve approach has been applied by a number of researchers such as Deaton and Subramanian, 1990 (India), Deaton, 1989 (Thailand and Cote d'Ivoire), Subramanian, 1995 (India), Ahmad and Morduch, 1993 (Bangladesh), Case and Deaton, 2003 (India) and the like.

Using data from rural India and consequently Pakistan, Kingdon (2005) and Aslam and Kingdon (2006) have used a variant of the Engle curve method hurdle models approach to confirm the existence of intra-household gender-bias. According to Kingdon (2005), gender-bias in child educational investment can be explained through two possible channels. First, through positive purchase for males and zero purchase for females. Second, conditional on positive purchases for both, lower expenditure on girl's schooling than boys.

Empirical studies from rural Ethiopia confirm the existence of gender-bias in child education. For instance, a very good work by Tekabe (2005) has attempted to explain differences in the cost of investment in terms of the child's inherent health endowment and their ability to receive education. The result suggests that educational investments are allocated to reinforce initial differences confirming the significance of bias in favor of the able children as they are motivated by return maximization. However, the study doesn't tell us at which stage does this bias occur. The objective of this study is to identify if there is any intra-household difference in household schooling investment among school age siblings. As there are two different channels of gender bias, bias at the initial stage of deciding on whether to enroll a child and the magnitude of resource allocated among enrolled siblings, we used a panel hurdle model that account for unobserved individual heterogeneity and initial conditions problem. To this end, we have used the Ethiopian Rural Household 
Survey (ERHS) panel data set spanning from 1994 to 2004 that enables us to control for a number of observed supply and demand factors as well as unobserved factors. The unique nature of our panel data set enables us to robustly detect the existence and magnitude of intra-household gender bias.

The rest of the paper is organized as follows. In the next section, we briefly present the current education policy and profile in Ethiopia. Section three discusses theoretical underpinning of intrahousehold resource allocation while section four presents the empirical strategies and data used in the study. Having discussed the descriptive and empirical findings in section five, the paper concludes with some policy implications in section six.

\section{Background and profile of educational system in Ethiopia}

There have been a number of international instruments geared towards gender equality in access to education, which Ethiopia has also ratified. Besides, the country's Education and Training policy aims at providing education on equal basis and in fact attention is given to gender issues through school materials and affirmative actions to girls in educational enrollment. In fact, Ethiopia has made progress in improving access to primary education since the 1990s. For instance, evidence from ERHS shows that it were only $67 \%$ of the sampled villages in 1997 that had access to primary school while the coverage has grown to 93\% in 2004 (see Table 5).

However, low enrollments, high gender and regional disparity, and low quality of education remained the major challenges of the education system (Chaudhury et al., 2006). There is a wide gender gap, both at the secondary and primary level. While the gap is declining for the primary cycle (grades 1-8) from that of $20 \%$ in $2000 / 01$ to $16.5 \%$ in $2004 / 05$, it is consistently increasing from as low as $4 \%$ in $2000 / 01$ to $14.8 \%$ in 2004/05 for the secondary cycle (grades 9-12) (see Table 1 in Annex). Trend of both the Gender Gap (GG) and Gender Parity Index (GPI) reflect consistently rising gender gap at the secondary cycle over time. In fact the micro data from the sixth wave of ERHS data (2004) shown in Figure 1 also confirm this claim that the divergence in gross enrollment rate (ER) between boys and girls increases for children 14 years and above, which corresponds with the secondary school cycle. 
Figure 1: Percentage of boys and girls currently enrolled by age - 2004

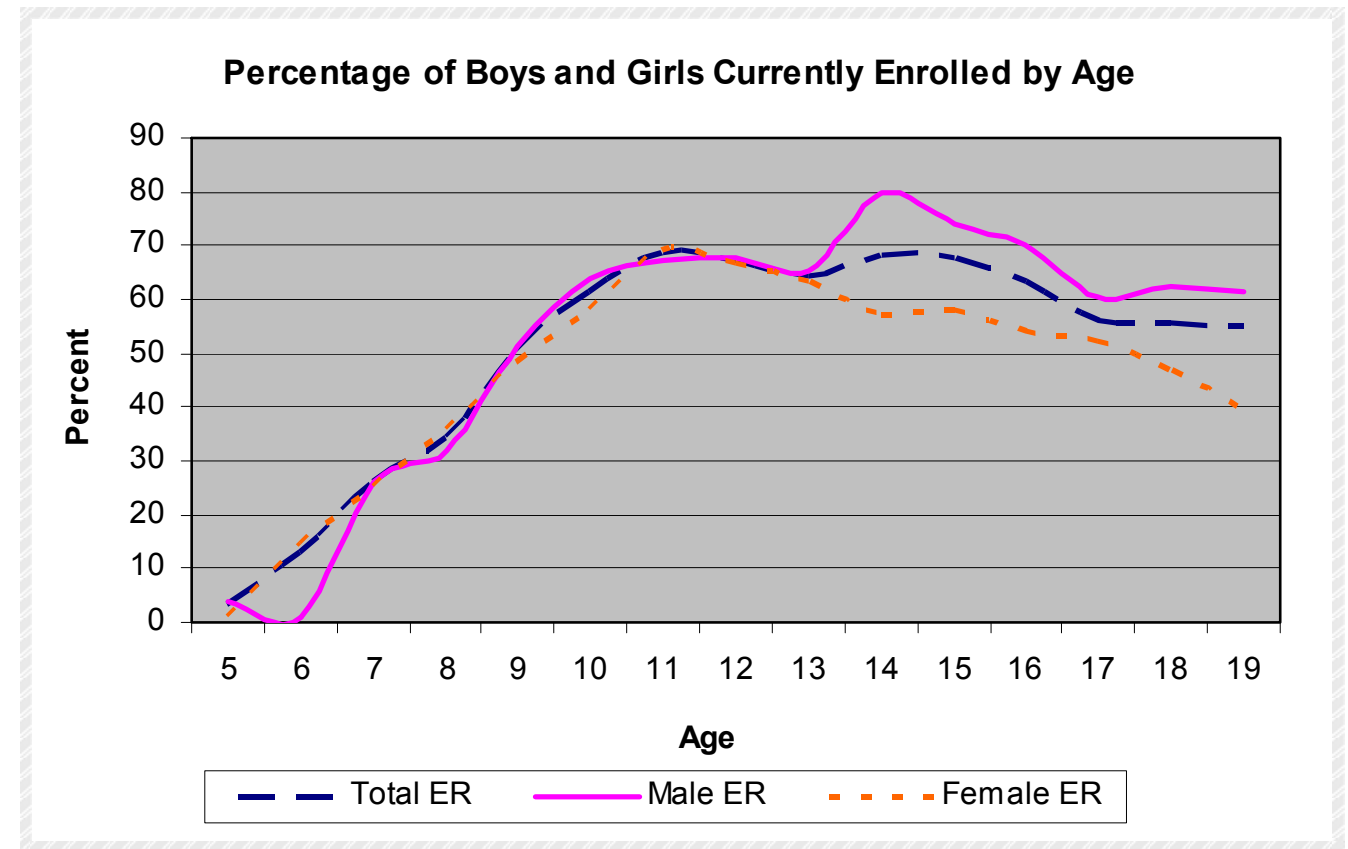

Source: Author's Calculation from ERHS 2004 data

There are multitudes of social, economic and cultural factors that deter girls' education. Economic factors like extreme poverty, socio-cultural nuisances such as harassment and violence including rape and early marriage; household discriminations and overburdened with household chores as girls time is close substitute to mothers' time in domestic activities, lack of follow-up and encouragement and unequal treatment compared to boys; etc increase the dropout rate of girls as well as hinder new enrollment (MoWA, 2005).

\section{Theoretical model of intrahousehold resource allocation and gender-bias}

If women, children, or old people are systematically worse off than other members of the household, the reported social welfare will be overstated (Deaton, 1997). Cognizant, in the development theory of intrahousehold resource allocation, there are different hypothesis as to how resources are allocated within the household. The simplest is the dictatorial/monotonic entities model, where households are assumed to be endowed with preferences as a single individual and the paterfamilias decides on behalf of everyone so that consumption behavior of the household will look like the 
behavior of individual consumer of the textbook. On the other extreme, we have the bargaining model, which considered households as a group of individuals who bargain with each other over resources (Deaton, 1997). The consequences of these different assumptions have been explored in the literature.

There are different presumptions as to why parents invest in their children human capital, the wealth model and the pure investment model, for instance. The wealth model presumes that parents can and are willing to substitute bequests for human capital investment and vice versa in order to maximize certain level of total life time wealth. The implication from this model is that, given differences in endowment, human capital and bequest of children, human capital investments reinforce initial endowment differences among siblings. The pure investment model, on the other hand, presumes that investments in human capital, like any other assets, depend on their net return. The marginal benefit and the marginal cost determine the level of investment in children, which is less influenced by the distributional consequences it involve (Behrman et al., 1982; Becker 1991, 1993). Depending on genetic endowments and supply of funds, parents influence the shape and the specific position of the marginal cost and the marginal benefit curves (Taubram, 1996 in Tekabe, 2005).

Models dealing with investment in children are mainly based on unitary household models that maximize a single parental utility. They focused on the distribution of parent-provided resources among children. It is deemed that parents care for the distribution of resources, human capital resources and bequests, among their children (Behrman 1997). Under this framework, parents maximize the household utility function with respect to parental consumption, bequests and children's earning's function. If the household is divided into two groups of members, parents $(A)$ and children $(B)$, the decision making rests on parents. Say, $q_{a}$ and $q_{b}$ are vectors of consumption goods for parents and children, respectively. The utility functions for the parents is given by $u_{a}\left(q_{a}, z\right)$. Given efficiency, the optimal choice of parents can be written as the solution to the problem;

$$
\operatorname{Max} u_{a}\left(q_{a}, z^{*}\right) \text { s.t. } \quad p_{a} \cdot q=l_{a}\left(p, p_{z}, y\right)
$$

Where, $\mathrm{z}^{*}$ is the optimal choice of public goods available for both groups, $p$ is the price vector for all goods, $p_{a}$ is the price of goods consumed by parents, $p_{z}$ is the 
price vector of public goods, and $l_{a}\left(p, p_{z}, y\right)$ is the sharing rule function that determines the total amount that parents gets conditional on the prices of goods, and total household resources $y$. The solution to the maximization problem is a set of demand functions of parents given by:

$$
q_{a i}=f_{p i}\left(x_{a}, p, g_{a}, g_{b}\right) \text { and } x_{a}=l\left(p, y, g_{a}, g_{b}\right)
$$

Where, $g_{a}$ and $g_{b}$ are characteristics of parents and children, respectively. The argument $x_{a}$ is the total expenditure that is allocated to adults by the sharing rule. As it is discussed in Deaton (1997), this is a well behaved demand function that holds widely for allocations based on bargaining or altruism. Here, children characteristics affect parents demand in two separate ways, through the amount that parents get through the sharing rule (income effects) and directly though the demand functions (substation effects).

Any change in child characteristics, say the addition of a child to the household, result in a reduction of adult consumption through income effect and rearrangements in adult consumption due to substitution effect which is required to feed, cloth or educate the child. If the sharing rule approach works, we should expect to find a greater negative effect on adult consumption of additional boys than of additional girls (Deaton, 1997).

\section{Model and empirical strategy}

\subsection{Empirical strategy}

From the theoretical underpinning of the demand function of parents for different household consumption goods, we have the standard Engle curve method appropriate to the problem under investigation. However, as there are different levels of decisions, the empirical model should be specified so as to account for the difference in decision behavior. The rationale behind the Engle curve approach is that household member composition according to different characteristics (sex, age, education, religion, ethnicity, etc) are a variables that exerts an impact on household consumption allocation pattern. In other words, household expenditure allocation to different purchases depends on the individual demand for a specific commodity and hence the household composition. Based on this economic rationale, an additional household member with specific individual characteristics affects the household's expenditure pattern in such a way as to increase expenditure on items of 
consumption associated with the additional member. By implication, the budget share of a good consumed by children increases as much when additional girl is added to the household as it does when an additional boy is added (Kingdon, 2005).

The Engle curve can be specified using the extended Working (1943) specification:

$\omega_{i t}=\alpha+\beta \ln \left(\frac{y_{i t}}{n_{i t}}\right)+\sigma \ln n_{i t}+\sum \delta_{k}\left(\frac{n_{k i t}}{n_{i t}}\right)+\gamma Z_{i t}+\varepsilon_{i t}$

Where, $\omega_{i t}$ is household budget share of education, $y_{i t}$ is total monthly consumption expenditure of the household, $n_{i t}$ is household size, $n_{\text {kit }}$ is the number of individuals in the $k$ th age-gender class within household $i, Z_{i t}$ is a vector of other household level characteristics, $\varepsilon_{i t}$ is the error term and $\mathrm{t}$ is survey round. $\alpha, \beta, \sigma, \delta_{k}$ and $\gamma$ are parameters to be estimated. The coefficient $\delta_{k}$ captures the effect of household composition on household budget allocations. The difference across gender can be tested using an F-test for the hypothesis that $H_{0}: \delta_{k m i}=\delta_{k f i}$. Where, $m, f$ and $k$ denote males, females and a given age group, respectively.

In many optimization problems corner solutions are common. For instance, amount of life insurance coverage chosen by an individual; family contribution to an individual retirement account; expenditure on some consumption goods like alcohol, cigarette; and firm expenditure on research and development, etc are circumstances of corner solutions. Likewise, we observe a significant proportion of the surveyed households reporting zero educational expenditure resulting in censoring of the dependent variable (see Table 3). Consequently, OLS estimation of Equation 3 is not appropriate, which yields biased parameters. First, when $y \geq 0, E(y \mid x)$ cannot be linear in $x$ unless the range of $x$ is fairly limited. Second, it also implies constant partial effects. Third, predicted values of $y$ can be negative for many combinations of $x$ and $\beta$, which yields downward biased parameters. Although, the tobit model is suggested as an alternative, it is identified only if the assumption of normality and homoskedaticity are fulfilled. In addition, it assumes a single mechanism to determine the choice between $\omega=0$ versus $\omega>0$ and the amount of $\omega$ given $\omega>0$. Specifically, $\frac{\partial P(\omega>0 \mid x)}{\partial x_{j}}$ and $\frac{\partial E(\omega \mid x, \omega>0)}{\partial x_{j}}$ have the same sign (Wooldridge 2002). 
Because of the two-tier nature of such a decision of whether to choose a positive $\omega$ or a zero $\omega$ and the decision of how much to spend conditional on purchasing a positive amount $(\omega \mid \omega>0)$, a Hurdle model is appropriate that allows initial decision of $\omega=0$ to be separate from the decision of how much $\omega$ given positive $\omega$ (Wooldridge, 2002). The model can be written as follows:

$\operatorname{prob}\left(\omega_{i t}=1 \mid x_{i t}\right)=\Phi\left(x_{i t} \theta\right)$

$\log \left(\omega_{i t}\right) \mid\left(x_{i t}, \omega_{i t}>0\right) \sim \operatorname{normal}\left(x_{i t} \psi, \sigma^{2}\right)$

Where, $x_{i t}$ is a vector of explanatory variables, $\theta$ and $\psi$ are parameters to be estimated and $\sigma^{2}$ is the variance.

We use random effects panel probit model for tier-one decision model and linear panel autoregressive random effects model for the second decision level, the decision on the magnitude of expenditure conditional on positive spending. The underlying specification of the tier-one hurdle model can be written as follows:

$$
\begin{aligned}
& \operatorname{prob}\left(\omega_{i t}=1 \mid x_{i t}, \alpha_{i}\right)=F\left(x_{i t} \theta+\varepsilon_{i t}\right) \\
& \varepsilon_{i t}=\alpha_{i}+e_{i t}
\end{aligned}
$$

Where, $\omega_{i t}$ is budget share of education in the total annual consumption expenditure of household $i$ in period $t$. It takes 1 if $\omega_{i t}>0$ and zero, otherwise. $\alpha_{i}$ captures household and individual specific time invariant and unobserved effects, $e_{i t}$ is a transitory error term assumed to be iid over time with a distribution $e_{i t} \sim \operatorname{normal}\left(0, \sigma_{e}^{2}\right)$.

There are a number of alternative techniques in a limited dependent variable panel data model to estimate Equation 6 that controls for the initial conditions problem and unobserved individual heterogeneity. Here, we use a two-step procedure suggested by Orme (1997) and Wooldridge (2005).

The traditional random effects models assumes that unobserved effects term is normally distributed and it is strictly independent from other regressors, i.e., , $\alpha_{i} \mid x_{i} \sim \operatorname{Normal}\left(0, \sigma_{c}^{2}\right)$, which is a strong assumption. As in the linear case, in 
many applications the point of introducing the unobserved effects, $\alpha_{i}$, is to explicitly allow unobservable to be correlated with some elements of $x_{i t}$. Using the Chamberlain's (1980) general specification to allow correlation between $\alpha_{i}$ and $x_{i t}$ and the Mundlak (1978) version, it can be assumed to have the following linear relation:

$$
\alpha_{i}=c_{0}+c_{1} \bar{X}_{i}+u_{i}
$$

Assuming $u_{i} \sim \operatorname{IN}\left(0, \sigma_{u}^{2}\right)$, which is independent of $x_{i t}$ and $e_{i t} \forall i$ and $t, c_{0}$ is the intercept and $\bar{x}_{i}$ is a vector of means of the time-varying covariates for household $i$ over time. Another problem is the initial conditions problem due to the correlation between $\omega_{i 1}$ and the unobservable, $u_{i}$, which needs to be controlled. It arises simply because the start of the observation period is different from the start of the stochastic process. Following Heckman (1981) and Wooldridge (2002), the reduced form random effect probit model for the tier-one expenditure process can be written as:

$\operatorname{prob}\left(\omega_{i t}=1 \mid x_{i t}, \ldots\right)=F\left(x_{i t} \theta+c_{1} \bar{x}_{i}+\delta \eta_{i}+\sum \varphi_{t v} D_{t v}+\xi_{i}+e_{i t}\right)$

Due to Orme $(1997)^{3}$, Equation 8 is a two-step estimable equation using standard statistical software, where $\eta_{i}$ is the Generalized Probit Error obtained from a probit estimation of the initial observation ${ }^{4}$. We also include regional and time dummies in Equation 8.

\footnotetext{
${ }^{3}$ For a detailed discussion and application of a two-step random effect probit model readers can consult Arulampalam et al., 1997.

${ }^{4}$ The correlation $\operatorname{corr}\left(\alpha_{i}, \eta_{i}\right)=\rho$ can be assumed to be linearly related as $u_{i}=\delta \eta_{i}+\xi_{i}$ '

where, $\eta_{i}$ and $\xi_{i}$ are assumed to be orthogonal to one another. The error term $\eta_{i}$ is obtained form

$\operatorname{prob}\left(\omega_{i 1}=1 \mid G_{i}, \ldots\right)=F\left(G_{i} \lambda+\eta_{i}\right)$
} 


\section{Tier-two hurdle model}

We can specify the positive educational spending Engle curve in panel data setting. In this specification, we allow the error terms to be correlated overtime. The model, which can be estimated using GLS, is written as:

$$
\begin{aligned}
& \log \left(\omega_{i t}\right) \mid\left(\ldots, \omega_{i t}>0\right)=\alpha+\beta \ln \left(\frac{y_{i t}}{n_{i t}}\right)+\sigma \ln n_{i t}+\sum \delta_{k}\left(\frac{n_{k i t}}{n_{i t}}\right)+\gamma Z_{i t}+\sum \varphi_{t v} D_{t v}+v_{i t} \\
& v_{i t}=\mu_{i}+\varepsilon_{i t} \\
& \mu_{i}=c_{0}+c_{1} \bar{x}_{i}+\zeta_{i} \\
& \varepsilon_{t i}=\rho \varepsilon_{i t-1}+e_{i t}
\end{aligned}
$$

Where, $\quad e_{i t} \sim N\left(0, \sigma_{e}^{2}\right)$ is orthogonal to $\mu_{i},|\rho|<1, \quad \zeta_{i} \sim \operatorname{iid}\left(0, \sigma_{\zeta}^{2}\right) \quad$ and $\operatorname{corr}\left(x_{i t}, \zeta_{i}\right)=0$. Like we did for the non-linear model, we allowed the unobservable to be correlated with some of the time varying correlates. All variables are as defined before. Finally, the complete models which can be computed using STATA or any other standard software packages are Equation 8 and Equation 9. To better control for observed and unobserved village level factors we have introduced village by round interaction terms, $\sum \varphi_{t v} D_{t v}$. The gain in efficiency of the overall model after the inclusion of these terms is dramatic. Besides, the term control for the role of covariate shocks and any market, infrastructure, political or socio-cultural developments as well as other supply side factors across villages and overtime. In fact, otherwise, gender-bias will be overstated. Since our observation is large, introducing these $14 \times 5$ terms should not be a concern to loss of degrees of freedom.

\subsection{The data}

Our analysis is based on the Ethiopian Rural Household Survey (ERHS) panel data set spanning from 1994-2004 collected by Addis Ababa University, Department of Economics in collaboration with the University of Oxford Center for the Study of African Economies (CSAE) and other institutions like the International Food Policy Research Institute (IFPRI). The survey was undertaken for six waves; 1994a, 1994b, 1995, 1997, 1999/2000 and 2004 consisting of a panel of 1400 households. The sampling was stratified to represent the main sedentary farming system in the country, the plough-based cereals farming system of the Northern and central Highlands, mixed plough/hoe cereals farming system and farming system based on 
enset in the southern parts of the country. Further more, sample size in each village was chosen so as to approximate a self-weighting sample, when considered in terms of the farming system. Fifteen Peasant Associations (PAs) in four regions are included in the panel. The survey is aiming at generating a multi-purpose data set comprising a range of household, community and market variables during each survey period. There are a number of modules included in the questionnaire. The attrition rate was very low, below $7 \%$, attributed to the fact that households in rural Ethiopia can not obtain land when moving to other areas (Dercon and Hodinot 2004). However, the survey does not cover pastoral areas in the country, which accounts for $10 \%$ of the total rural population.

\subsection{Description and definition of variables}

In this study, we used a household level data to identify intra-household gender-bias in the allocation of educational spending. Although, the ERHS data have information on some individual level variables, we preferred to use household level data to minimize measurement error. The dependent variable is share of spending on education. For the first-tier hurdle model, we used a dichotomous variable taking unity, if household allocate resources on child schooling. While for the tier-two model, we used log transformation of the share of educational spending in the total household consumption budget, conditional on positive spending. As can be shown in Figure 1, this is a valid transformation that reduces noise in the regression. The log transformed share of education (panel 4), after scaling up, is normally distributed than the unconditional and conditional level forms (panels 1 and 2). In the questionnaire, all school related direct expenses such as fees, uniforms, materials like book, contributions and club fees, accommodation and transportation to school are merged under school fees and other educational expenses. It should be noted that for primary cycle, there is no school fee in public schools. Besides, mindful of the indirect costs of sending children to school in rural areas, we included variables that capture the opportunity cost such as land ownership, livestock owned, oxen and the level of welfare of the household.

In the right hand side of our equations, we have the proportion of boys and girls in the household in each age-sex grouped into fourteen categories (below 4, 5-9, 10-14, 15$19,20-24,25-60$, and over 60 years old) for both sexes as regressors. Age-sex group over 60 years are considered as reference group. Other household level characteristics like sex of the head (dummy=1 if male and zero otherwise), age of the head, level of education of the head, mean age in the household, lagged value of log of consumption per adult equivalent unit, size of land holding in hectare, number of 
livestock owned, number of oxen owned, and interaction of round by village dummies, over time mean values of time-varying household level variables and first difference of these variables are included. Summary statistics of these variables are shown in Table 3.

\section{Discussion of results}

\subsection{Descriptive statistics}

In this section the descriptive part of the analysis is presented. Spending on child education is an important aspect of human capital investment. However, evidences from rural Ethiopia, such as Assefa (2002) show that sending children to school has an opportunity cost as their labor is needed for domestic, farm activities or activities. As can be shown in Table 3, the percentage of households with one or more school age children (5-19 years) spending a positive amount of educational expenditure is around $21.64 \%$. The worst figure is observed in the case of Ankober in Amhara Region, where the percentage of households who have school age children in the household that allocate positive amount on child education is only $13 \%$.

Of those who allocate resources to siblings schooling, the level of budget share on education is only $1.3 \%$ of total expenditure in the survey areas. Conditional on enrollment, from the sample weredas households residing in Kedida Gamela spend the highest proportion of their budget, $2 \%$, on child schooling. While households in Ankober spend very small, only $0.6 \%$, proportion of their household budget. It is very interesting to figure out that compared to other regions, households residing in Amhara region (Ankober, Debre Birhan, Enemayi, and Bugna) have the lowest budget share for education, less than $1 \%$, given households have already decided to spend some positive amount on child education. This could be due to a variety of supply, demand and policy factors on the ground. We cannot simply generalize that households in these areas have lower preference to child education and we need to assess all other factors.

Table 4 presents the proportion of children in households with positive educational spending by gender and age. We can observe that, in the three school age categories; 5-9 years, 10-14 years and 15-19 years, it is those households with the highest proportion of boys who incur the largest magnitude of positive educational expenditure. 


\subsection{Empirical results}

\subsubsection{Determinants of resource allocation to child schooling}

It is imperative to understand the determinants of intra-household allocation of resources to child education. Beside supply side factors, demand side factors are important in determining the level of school enrollment, completion and rate of success. The demand side is determined by a number of factors; social, cultural, economic and household level preference and characteristics. As can be seen from the regression results in Table 6, sex and age of the individual as well as a number of household level factors determine the behavior of household resource allocation to child education investment.

It is appealing to note that the coefficient of male headship is negative but insignificant in the random effects probit regression equation while negative and significant at $5 \%$ on the decision of how much to spend. This implies that male headed households shift away resources from investment in child education. That is, cetirus paribus, male headed households have negative taste to child schooling presumably due to higher preference to adult commodities than children education. It reflects the uneven bargaining power of men and women in the household on intrahousehold resource allocation and reinforces the evidence that women headed households tend to allocate more resources to siblings schooling.

The level of education of the head, on the other hand, has a positive impact on the decision to allocate resources to education and its magnitude. We observe households with higher proportion of pre-school age children, below 4 years, tend to shift away their resources from child schooling, usually to nutrition, health, clothes and other purchases.

Although, in column [1] enrollment increases with the increase in household size, from the coefficient of the squared variable it is shown that very large household size discourages enrollment significantly. Except in Tigray, the coefficient on natural log of household size is positive and significant in Amhara, Oromia and SNNP ${ }^{5}$. However, from the conditional regression, we found a negative and statistically significant impact of household size on the magnitude of share of education in Tigray and Oromia region. The elasticity of share of education to household size is -2.21 and -1.1 implying a $1 \%$ decrease in the household size leads to $2.21 \%$ and $1.1 \%$ increase in the share of educational budget in Tigray and Oromia, respectively.

\footnotetext{
${ }^{5}$ SNNP stands for Southern Nations Nationalities and People
} 
From the whole sample and Oromia region, we found that having more of both oxen and land have a negative impact on the initial decision to send children to school, which echoes the importance of farm opportunity cost of sending children to school. However, once they have decided to send their children to school, having more land and oxen have positive and statistically significant impact of increasing the magnitude of resource allocated to schooling. This is because the most important rural productive assets are land and oxen. Land is the central source of livelihood while oxen are the major source of traction power and store of wealth. Having more of these assets, increases the capacity of the households to cover school expenditure.

Land ownership has significant and negative impact on school enrollment in Tigray and Amhara regions, again reflecting the opportunity cost of sending children to school. On the other hand, the result from Oromia region is contrary to this finding where owning more of cultivable land increases the probability of child enrollment. Possible reasons may be productivity differences in adult labor and agro-ecological setup as Oromia and SNNP are surplus regions in the country resulting in less demand for child labor on farm activities. As the number of oxen owned increases by one unit, the probability of allocating positive educational resources is $5 \%, 3 \%$ and $6 \%$ in Tigray, Amhara and Oromia regions respectively. Generally, the direction and level of significance of asset holding is mixed across regions and stages of decision.

As it can be shown in column [1], the lagged value of log of consumption has positive sign in both stages of decision and it is significant at $1 \%$ in tier-two decision. Households with higher welfare, invest more on education, where doubling the level of consumption (total budget) leads to $10.4 \%, 25.8 \%, 15.8 \%$ and $12.7 \%$ increases in share of educational expenditure in Ethiopia as a whole, Tigray, Amhara and SNNP regions, respectively. This implies that for high income households, children are not needed to engage in income generating or productive activities to augment household income at the expense of their schooling.

\subsubsection{Detecting gender-bias}

When trying to identify intra-household bias, one has to be cautious not to overstate/understate it since bias may arise due to a number of factors and model specification. A number of factors should be controlled both spatially and overtime. There are observed and unobserved, individual, household and village level effects that may lead to the observed level of gender-bias. For instance, individual talent or intelligence in schooling, behavior, level of effort and success in school and other factors may influence the preference to allocate positive or zero sum of resources to child schooling. Along with deciding on the appropriate empirical model, one has to 
better suit to panel data set that tracks the same household over a long period of time as it enable to control for time invariant individual, household and community specific effects. The salient feature of our analysis is to make use of this advantage.

From the probit regression model of the whole sample, we observe that there are positive and statistically significant coefficients on male and female children aged between 5 and 19 years. That is, households with one or more member of this age category tend to allocate resources to education. However the magnitude and level of significance of these coefficients vary among different age-sex groups and regions like in Amhara and Oromia. Except in Tigray, magnitude of the coefficients is larger for boys than girls. For instance, the probability of allocating a positive resource to male children aged $10-14$ years is $60.68 \%, 39.27 \%, 75.06 \%$ and $78.6 \%$ as compared to female children whose probability of getting enrolled is $47.99 \%, 14 \%, 46.44 \%$ and $62.86 \%$ for the whole sample, Amhara, Oromia and SNNP regions, respectively. That is, the probability of allocating a positive educational resource is 0.61 for the next boy and 0.5 for the next girl aged 10-14. Likewise, the magnitude of these probabilities in age group 5-9 and 15-19 years are higher for male children.

From regionally disaggregated marginal coefficients of probit estimation, we observe that the direction of most of the coefficients is theoretically consistent. However, it is only in the case of age-sex categories of male_10-14 and female_10-14 for Tigray; male_10-14 for Amhara; male_5-9, male_10-14 and female_10-14 for Oromia; male_5-9, male_10-14, female_10-14, male_15-19 and female_15-19 for SNNP that these coefficients are positive and statistically significant. This implies that an additional child of that specific age category to the household and region has a positive probability of being enrolled to school.

To give statistical validity of our claim over the existence of gender-bias in the intrahousehold resource allocation in child educational investment, we test the hypothesis $H_{0}: \delta_{k m i}=\delta_{k f i}$, which can be accomplished by a Wald-test on the marginal effects of the coefficients of interest (school age children; 5-9 years, 10-14 years and 15-19 years). From the probit marginal effects of the whole sample and SNNP, in Table 7, we found that there is statistically significant pro-boy bias in educational enrollment in the age category of 15-19 years. That is households in rural Ethiopia discriminate against girls who are in the age range of 15-19 years. This age category corresponds to the secondary school (secondary cycle). Unlike other regions, households in Amhara significantly discriminated against girls school enrollment compared to boys aged 10-14 years. The risk in this discrimination is that it denies girls their very chance of being enrolled in school. However, except in 
Oromia, test result from the conditional regression indicates that those households who have initially decided to incur positive school expenses do not discriminate against girls by reducing the magnitude of the resource.

One reason why we couldn't verify pro-boys bias in primary and junior school age children in most of the regions and the whole sample is that in many places there is no school fee at these levels. Besides, in most of the sample areas access to primary schools is relatively better, which will have positive impact by reducing transport cost, allowances, and other expenses. However, when children are promoted to high school, they have to travel to the nearest town. In most cases, they have to stay for a week or more. From Table 5, we can see that it is only $20 \%$ of the sampled villages which have a secondary school in the village and the average distance to the nearest town with high school is about $11 \mathrm{~km}$ in 2004 . In this case, the cost of sending children to school becomes significant. Further more, traveling long distance to school in cases where there is no suitable road infrastructure is difficult for girls, which forces them to frequently dropout school.

Households are also reluctant to send their girls far from home fearing abuses and sexual harassment by schoolmates and men teachers. Hence, lack of access to school infrastructure in the village by itself may induce endogenous bias against sending girls to school. In addition, girls' role in the household is important and their time is a close substitute to mothers' time in domestic activities. This age category also corresponds to girls' marriage in most rural areas forcing them to dropout. Parents also may hesitate to invest on their daughters' than their sons' education as they expect low rate of return and low expected transfer to parents during old age. However, as we have observed, if households have found way of sending girls to school, no statistically significant evidence is found to reduce the resource against them. However, it is important to note that once households have decided to incur positive child educational expenditure, there is pro-girls bias in the age category of 10-14 years and significant pro-boy bias in the age category of 15-19 years in Oromia region.

Tigray region is the only exception with no statistically significant gender-bias against girls in both the decision to enroll and the decision on the magnitude of share of budget allocated to child schooling. Interestingly, our finding is consistent with the official macro data, where the Gender Gap and Gender Parity Index is consistently rising at the secondary cycle. Figure 2 also indicates that the enrollment rate for boys diverges significantly from that of girls aged 14 years and above. As we have discussed above, the pro-boys bias is pervasive during the initial decision to enroll children to school (or whether to incur positive educational expenditure or zero) in the 
age category of $15-19$ years, which corresponds to secondary school in Ethiopian educational system.

\section{Conclusion and policy implications}

In this study, we examined whether there is any intra-household gender-bias in household educational resources allocation to boy and girls. Gender-bias may occur at two stages, the initial decision to enroll children to school and conditional on enrollment, whether households discriminate on the amount of the resource based on gender. This is of interest because at the national level, official data reveals the existence of gender gap both at the primary and secondary cycles. The trend shows that this gap is falling for the primary cycle, while it has been rising in the secondary cycle. This bias could be an outcome of a number of multiplicative factors, both from the supply and demand side. Micro evidence from the ERHS 2004 data also reveals divergence in gross enrollment rate between boys and girls for those aged 14 years and above.

The main objective of this study has, therefore, been to uncover if there is any intrahousehold gender bias on the allocation of resources to child education and during which stage of decision. Using a panel data set from ERHS, spanning from 19942004, we have tried to detect any intra-household gender bias in rural areas. The panel nature of our data set enabled us to control for observed and unobserved effects and initial condition problems. We applied panel hurdle model consisting of two regressions; random effects probit for the initial decision on enrollment and linear autoregressive random effects model on the proportion of the educational resource conditional on enrollment.

From the descriptive results we note that the percentage of households in rural Ethiopia with one or more children who allocate positive amount of resource to their children's education is around $21.64 \%$ of the sample. The average budget share of spending on child schooling of these households is only $1.3 \%$. We have also observed that it is those households with the highest proportion of boys who frequently incur positive educational expenditure or send their child to school.

Irrespective of the gender of the child, households with male headship have negative taste to child educational investment. Although, large family size has positive and significant impact on child school enrollment, it has an inversely proportional impact on the budget share allocated to education. Having more of both rural farming land and oxen has negative impact on enrollment signifying the opportunity cost of 
sending children to school. Nevertheless, once they are enrolled, more of rural productive assets have positive and significant impact on the magnitude of the share allocated to child schooling. Households with high level of welfare allocate higher share of their budget expenditure to schooling.

After controlling for a number of observed and unobserved effects, we found that coefficients on male and female children aged between 5 and 19 years are statistically significant. From the whole sample, the observed probability of an additional school age child getting enrolled is higher if it is a boy as compared to a girl. The Wald-test on the marginal coefficients indicates that there is a significant gender bias during the initial decision against girls in the age range of 10-14 years in SNNP and in the age range of 15-19 years for the whole sample and SNNP. However, significant pro-boy bias in the primary school cycle ages, $5-9$ years is not observed. From the whole sample, we couldn't also find gender-bias on the budget share allocated, once households have decided to enroll their child. However, there are mixed results in some places. Such as in Oromia region, we found significant pro-girls bias on the share of education allocated to enrolled children in the age category of 10-14 years and pro-boy bias in the age category between 15 and19 years. The existence of gender-bias in the secondary cycle age children could be due to the absence of high school in the village that buttressed the gender discrimination in enrollment and resource allocation against girls in the age range of 15-19 years. The only region that we couldn't detect significant gender-bias during both decisions is Tigray.

The implication of our study is that policies that are geared towards increasing human capital should take into account the existence of significant intrahousehold bias against girl's education, especially among those who are aged 14 years and above. Since the bias occurs inside the household, public investments should not only focus on facilitating access to school but also work from the demand side as parents have different preference towards siblings' education. Gender specific direct and indirect policy interventions are important at correcting the demand side bottlenecks in poor areas. Policies that increase the returns to girl's education in the labor market could increase parents' preference towards daughter's educational investment. Besides other affirmative actions, supply side targeting of girls in through scholarships and incentives could also mitigate the problem. Besides, a broader objective of increasing labor productivity in rural areas it should also consider increasing intrahousehold productivity so as to reduce the overburden of mothers since girls labor could be a close substitute to their domestic activities. This can be accomplished by increasing access to clean water, grain mill, market infrastructure, alternative sources of energy, etc. Legislations that prohibit early marriage could also reduce the incidence of girls' dropout from school. 


\section{Reference}

Afridi, F. 2005. Intra-household Bargaining, Birth Order and the Gender Gap in Schooling in India, (Unpublished), Presented at the 2005 Annual Meeting of the Population Association of America, Philadelphia, Pennsylvania, March 31 - April 2, 2005.

Ahmad, A. and Morduch, J. 1993. Identifying Sex Bias in the Allocation of Household Resources: Evidence from Limited Household Surveys from Bangladesh. Mimeo, Harvard University, Department of Economics.

Assefa, A. 2002. The Implication of Asset Ownership on Child Work in Rural Ethiopia. Ethiopian Journal of Economics, Vol. 11, No. 2, pp. 25-58.

Aslam M. and Kingdon G. G. 2006. Gender and Household Educational Expenditure in Pakistan. Economic and Social Research Council, Global Poverty Research Group, GRPG-WPS-025. www.gprg.org

Berhman, J. 1982. Intra-household Distribution and the Family. In Handbook of Population and Family Economics, Vol. 1A, ed. Mark Rosenzweig and Oded Stark. Amsterdam: Elsevier/North Holland.

Becker, G. S. 1991. A Treatise on the Family. $2^{\text {nd }}$ ed. Cambridge, MA: Harvard University Press. 1993. Human Capital: A Theoretical and Empirical Analysis with Special Reference to Education. $3^{\text {rd }}$ ed. Chicago: University of Chicago Press.

Behrman, J., Robert A. Pollak and Taubman, P. 1982. Parental Preference and Provision of Progeny. Journal of Political Economy, Vol. 50, pp. 52-73.

Case, A. and Deaton, A. 2003. Consumption, Health, Gender and Poverty. The World Bank Poverty Reduction and Economic Management Network, Working Paper No. 3020.

Chamberlain, G. 1980. Analysis of Covariance with Qualitative Data, Review of Economic Studies 47, 225-238.

Chaudury, N., Christiaensen, L., \& Asadullah, M. N. 2006. Schools, Household, Risk and Gender: Determinant of Schooling in Ethiopia. Centre for the Study of African Economies: Oxford.

Cochrane, S. H. 1979. Fertility and Education: What do We Really Know? The World Bank Staff Occasional Paper, No. 26, Baltimore, USA.

Dasgupta, P. 1993. An Inquiry into Well-Being and Destitution. Oxford: Clarendon, United Kingdom.

Deaton A. 1997. The Analysis of Household Survey: A Micro-econometric Approach to Development Policy. Published for the World Bank, The Johns Hopkins University Press, Baltimore and London. 1989. Looking for Boy-girl Discrimination in Household Expenditure Data. World Bank Economic Review. 3, 1-15.

Deaton, A. and Subramanian, S. 1990. Gender Effects in Indian Consumption Patterns. Sarvekshanan 12, 1-12.

Dercon, S. and Hoddinott, J. 2004. The Ethiopian Rural Household Survey: Introduction. International Food Policy Research Institute, Washington D.C. 
Dercon, S. and Krishnan, P. 1997. In Sickness and in Health: Risk Sharing within Households in Rural Ethiopia. Discussion Paper Series 97.18, Center for Economic Studies, Katholieke Universiteit Leuven.

Ellis, F. 2000. Rural Livelihoods and Diversity in Developing Countries. Oxford University Press Inc. New York.

Haddad, L. and Hoddinott, J. 1995. Does Female Income Share Influence Household Expenditures? Evidence from Cote d'Ivore. Oxford Bulletin of Economic and Statistics, Vol. 57, pp.77-96.

1994. Women's Income and Boy-girl Anthropometric Status in Cote d'Ivoire. The World Bank, Vol. 22, pp. 543-553.

Hazarika, G. 2000. Gender Differences in Children's Nutrition and Access to Health Care in Pakistan. The Journal of Development Studies 37, 73-92.

Heckman, J. J. 1981. The Incidental Parameters Problem and the Problem of Initial Conditions in Estimating a Discrete Time - Discrete Data Stochastic Process, in C. F. Manski and D. McFadden (eds.). Structural Analysis of Discrete Data with Econometric Applications. Cambridge: MIT Press.

Kingdon, G. G. 2005. Where Has All the Bias Gone? Detecting Gender Bias in the Intrahousehold Allocation of Educational Expenditure. Economic Development and Cultural Change 53, 409-451.

Mincer, J. 1974. Schooling, Experience and Earnings. National Bureau of Economic Research (NBER). New York.

Ministry of Women's Affairs (MoWA). 2005. Gender Relations in Ethiopia. Ministry of Women's Affairs, Addis Ababa, Ethiopia.

2006. National Action Plan for Gender Equality, 2006-2010. Ministry of Women's Affairs, Addis Ababa, Ethiopia.

Mundlak, Y. 1978. On the Pooling of Time Series and Cross Section Data. Econometrica Vol. 46: pp. $69-85$.

Orme, C. D. 1997. The Initial Conditions Problem and Two-Step Estimation in Discrete Panel Data Models. Mimeo, University of Manchester, Uk.

Quisumbing, A., Lynn, R. B., Hilary, S. F. Lawrence, H. and Christine, P. 1995. Women: The Key to Food Security, Food Policy Report. International Food Policy Research Institute, Washington D.C.

Quisumbing, A. R. and Maluccio, J. A. 2000. Intra-Household Allocation and Gender Relations: New Emperical Evidence from Developing Countries. International Food Policy Research Institute (IFPRI), FCND Discussion Paper No. 84, Washington, DC.

Rosensweig, M. R. and Shultz, T. P. 1982. Market Opportunities, Genetic Endowments, and Intrafamily Resource Distribution: Child Survival in Rural India. The American Economic Review 72, 803-815.

Rosensweig, M. R. and Wolpin, K. 1988. Heterogeneity, Intrafamily Distribution and Child Health. Journal of Human Resources, Vol. 23, pp. 437-461.

Strauss, J. and Thomas, D. 1995. Human Resources: Empirical Modeling of Household and Family Decisions. In Handbook of Development Economics, ed. Jere Berhman and Thirukodikazal Srinivasan, Vol. 3A, Amsterdam: Elsevier/North Holland. 
Subbaro, K. and Ranley, L. 1995. Social Gains from Female Education: A Cross-National Study. Economic Development and Cultural Change, Vol. 44, pp.103-128.

1992. Social Gains from Female Education, Policy Research Working Paper No. 1045, The World Bank, Washington, USA.

Subramanian, S. 1995. Gender Effects in Intra-Household Allocation in India. Unpublished Memeo, Cornell University, Department of Economics.

Taubman, P. 1996. The Role of the Family in the Formation of Offsprings, Earnings and Income Capacity. In Household and Family Economics, ed. Paul Menchik, Boston: Kluwer Academic.

Tekabe, A. 2005. Parental Preference, Heterogeneity, and Human Capital Inequality. Economic Development and Cultural Change, vol 53 (2005), pp. 381-407.

Thomas, D. 1994. Like Father, Like Son; Like Mother, Like Daughter Parental Resource and Child Height. The Journal of Human Resources, Vol. 29, pp. 950-988. 1990. Intra-Household Resource Allocation: An Inferential Approach. The Journal of Human Resources, Vol. 25, pp. 635-664.

UNICEF. 2007. The State of The World's Children 2007. UNICEF NY, 3 UN Plaza, NY, NY 10017, USA.

Wooldridge, Jeffrey M. 2002. Econometric Analysis of Cross Section and Panel Data. Cambridge, Mass.: MIT Press.

2005. Simple Solution to the Initial Conditions Problem in Dynamic, Non-Linear Panel Data Models with Unobserved Heterogeneity. Journal of Econometrics, Vol. 20, pp. 39-54. 


\section{Annexes}

Table 1: Trends in Gross Enrollment Ratios at Primary and Secondary Education by Sex

\begin{tabular}{|c|c|c|c|c|c|c|}
\hline & Year & $2000 / 01$ & $2001 / 02$ & $2002 / 03$ & $2003 / 04$ & $2004 / 05$ \\
\hline \multirow{5}{*}{ Primary Cycle } & Total & 57.4 & 61.6 & 64.4 & 68.4 & 79.8 \\
\hline & Boys & 67.3 & 71.7 & 74.6 & 77.4 & 88 \\
\hline & Girls & 47 & 51.2 & 53.8 & 59.1 & 71.5 \\
\hline & GG & 20.3 & 20.5 & 20.8 & 18.3 & 16.5 \\
\hline & GPI & 0.7 & 0.71 & 0.72 & 0.76 & 0.81 \\
\hline \multirow{5}{*}{ Secondary Cycle (9-10) } & Total & 14.1 & 17.1 & 19.3 & 22.1 & 27.3 \\
\hline & Boys & 16.1 & 20.4 & 24 & 28.2 & 34.6 \\
\hline & Girls & 12.1 & 13.7 & 14.3 & 15.9 & 19.8 \\
\hline & GG & 4 & 6.7 & 9.7 & 12.3 & 14.8 \\
\hline & GPI & 0.75 & 0.67 & 0.6 & 0.56 & 0.57 \\
\hline
\end{tabular}

Source: Author's Calculation from ERHS data Note: Values in bracket are Standard Deviations

Table 2: Educational spending in households with one or more children aged between 5-19 years: $1994-2004$

\begin{tabular}{|c|c|c|c|c|}
\hline & Wereda & $\begin{array}{c}\text { Share of Education in } \\
\text { Total Budget among } \\
\text { all HHs }\end{array}$ & $\begin{array}{l}\text { \% of HHs Spending } \\
\text { Positive Educ'l } \\
\text { Expenditure }\end{array}$ & $\begin{array}{c}\text { Share of education in Total } \\
\text { Budget among HHs spending } \\
\text { Positive Amount }\end{array}$ \\
\hline \multirow{4}{*}{ Tigray } & \multirow{2}{*}{ Atsbi } & 0.003 & $20.12 \%$ & 0.011 \\
\hline & & $(0.007)$ & $(.401244)$ & $(0.011)$ \\
\hline & \multirow{2}{*}{ Sebhaassahsie } & 0.004 & $25.36 \%$ & 0.014 \\
\hline & & $(0.011)$ & $(.4356109)$ & $(0.016)$ \\
\hline \multirow{8}{*}{ Amhara } & \multirow{2}{*}{ Ankober } & 0.001 & $12.92 \%$ & 0.006 \\
\hline & & $(0.003)$ & $(.3357506)$ & $(0.005)$ \\
\hline & \multirow{2}{*}{ Derbe Birhan } & 0.002 & $25.77 \%$ & 0.007 \\
\hline & & $(0.007)$ & $(.4375416)$ & $(0.011)$ \\
\hline & \multirow{2}{*}{ Enemayi } & 0.003 & $26.72 \%$ & 0.009 \\
\hline & & $(0.008)$ & $(.4430819)$ & $(0.012)$ \\
\hline & \multirow{2}{*}{ Bugena } & 0.002 & $17.48 \%$ & 0.009 \\
\hline & & $(0.007)$ & $(.3799863)$ & $(0.015)$ \\
\hline \multirow{8}{*}{ Oromoria } & \multirow{2}{*}{ Adaa } & 0.002 & $18.73 \%$ & 0.011 \\
\hline & & $(0.007)$ & $(.3904634)$ & $(0.013)$ \\
\hline & \multirow{2}{*}{ Kersa } & 0.004 & $24.24 \%$ & 0.016 \\
\hline & & $(0.012)$ & $(.4289108)$ & $(0.019)$ \\
\hline & \multirow{2}{*}{ Dodota } & 0.004 & $30.22 \%$ & 0.013 \\
\hline & & $(0.010)$ & $(.4595619)$ & $(0.014)$ \\
\hline & \multirow{2}{*}{ Shashemene } & 0.008 & $45.15 \%$ & 0.016 \\
\hline & & $(0.014)$ & $(.4980211)$ & $(0.017)$ \\
\hline \multirow{10}{*}{ SNNP } & \multirow{2}{*}{ Cheha } & 0.004 & $30.91 \%$ & 0.013 \\
\hline & & $(0.010)$ & $(.4627142)$ & $(0.014)$ \\
\hline & \multirow{2}{*}{ Kedida Gamela } & 0.008 & $37.08 \%$ & 0.020 \\
\hline & & $(0.015)$ & $(.4835319)$ & $(0.019)$ \\
\hline & \multirow{2}{*}{ Bule } & 0.002 & $13.02 \%$ & 0.013 \\
\hline & & $(0.007)$ & $(.3367171)$ & $(0.013)$ \\
\hline & \multirow{2}{*}{ Boloso } & 0.004 & $25.53 \%$ & 0.015 \\
\hline & & $(0.010)$ & $(.441872)$ & $(0.015)$ \\
\hline & \multirow{2}{*}{ Daramalo } & 0.005 & $31.32 \%$ & 0.014 \\
\hline & & $(0.012)$ & $(.4681633)$ & $(0.017)$ \\
\hline Whole & \multirow{2}{*}{ Total } & 0.003 & $21.64 \%$ & 0.013 \\
\hline Sample & & $(0.009)$ & $(.4118043)$ & $(0.015)$ \\
\hline
\end{tabular}


Andinet Delelegn: Intra-household gender-bias in child educational...

\begin{tabular}{|c|c|c|c|}
\hline Variable & Description & Mean & Std. Dev. \\
\hline \multicolumn{4}{|c|}{ Dependent Variables } \\
\hline Monthly Educ Expenditure-Conditional & Monthly Expenditure on School fees and Other school related expenses & 7.220138 & 24.5932 \\
\hline Share of Education - Unconditional & Share of Monthly Educational expenditure in total consumption expenditure & 0.002782 & 0.0088 \\
\hline Share of Education - Conditional & Share of Monthly Educational expenditure in total consumption expenditure conditional on positive expenditure & 0.010845 & 0.014645 \\
\hline Dummy of positive educ spending & Dummy $=1$, if the household spends positive expenditure on education & 0.216393 & 0.411804 \\
\hline \multicolumn{4}{|c|}{ Ratio of Age-Sex Category to Household Size } \\
\hline Male_below4 & Ratio of number of male children aged below 4 years to total household size & 0.043624 & 0.092472 \\
\hline Female_below4 & Ratio of number of female children aged below 4 years to total household size & 0.040729 & 0.088702 \\
\hline Male_5-9 & Ratio of number of male children aged between 5-9 years to total household size & 0.05847 & 0.097007 \\
\hline Female_5-9 & Ratio of number of female children aged between $5-9$ years to total household size & 0.059446 & 0.096026 \\
\hline Male_10-14 & Ratio of number of male children aged between $10-14$ years to total household size & 0.058933 & 0.102086 \\
\hline Female_10-14 & Ratio of number of female children aged between $10-14$ years to total household size & 0.057296 & 0.103536 \\
\hline Male_15-19 & Ratio of number of male children aged between $15-19$ years to total household size & 0.0522 & 0.107183 \\
\hline Female_15-19 & Ratio of number of female children aged between $15-19$ years to total household size & 0.052441 & 0.108422 \\
\hline Male_20-24 & Ratio of number of male children aged between $20-24$ years to total household size & 0.039464 & 0.100251 \\
\hline Female_20-24 & Ratio of number of female children aged between $20-24$ years to total household size & 0.041516 & 0.102122 \\
\hline Male_25-60 & Ratio of number of male children aged between $25-60$ years to total household size & 0.144622 & 0.15154 \\
\hline Female $25-60$ & Ratio of number of female children aged between $25-60$ years to total household size & 0.165181 & 0.155925 \\
\hline
\end{tabular}


Ethiopian Journal of Economics, Volume XVI, No 2, October 2007

\begin{tabular}{|c|c|c|c|}
\hline \multicolumn{4}{|c|}{ Household Characteristics } \\
\hline Head_sex & Dummy $=1$, if the household head is male, zero otherwise. & 0.769687 & 0.421061 \\
\hline Head_age & Age in years of head of the household & 48.06955 & 15.56917 \\
\hline Head_primedu & Dummy $=1$, if the household head 's level of education is primary school & 0.151524 & 0.358583 \\
\hline Head_junedu & Dummy $=1$, if the household head 's level of education is Junior school & 0.028954 & 0.167688 \\
\hline Head_secedu & Dummy $=1$, if the household head 's level of education is Secondary school & 0.019027 & 0.136628 \\
\hline In of hh size & Natural logarithm of household size & 1.687668 & 0.566128 \\
\hline In of hh size sqr & Natural logarithm of household size squared & 3.168691 & 1.722574 \\
\hline Household_mean age & Mean age in the household & 24.41835 & 10.59169 \\
\hline land & Size of land owned by the household measured in hectar. & 1.827598 & 2.125061 \\
\hline livstk_no & Number of livestock owned, except oxen and bulls & 8.941679 & 11.66209 \\
\hline Oxen_no & Number of oxen and bulls owned & 0.946643 & 1.98277 \\
\hline Amhara & & 0.274199 & 0.44613 \\
\hline Oromia & & 0.360171 & 0.480072 \\
\hline SNNP & & 0.280477 & 0.449253 \\
\hline
\end{tabular}


Table 4: Proportion of children in households with positive educational spending

\begin{tabular}{|c|c|c|c|c|c|c|}
\hline \multirow[t]{2}{*}{ Wereda } & \multicolumn{2}{|c|}{$\begin{array}{c}\text { Proportion of children } \\
5-9 \text { years }\end{array}$} & \multicolumn{2}{|c|}{$\begin{array}{l}\text { Proportion of children } \\
10-14 \text { years }\end{array}$} & \multicolumn{2}{|c|}{$\begin{array}{c}\text { Proportion of children } \\
15-19 \text { years }\end{array}$} \\
\hline & Mal e & female & male & female & male & female \\
\hline \multirow{2}{*}{ Atsbi } & 0.079 & 0.059 & 0.085 & 0.069 & 0.042 & 0.058 \\
\hline & $(0.113)$ & $(0.102)$ & $(0.120)$ & $(0.103)$ & $(0.087)$ & (0.095) \\
\hline \multirow{2}{*}{ Sebhaassahsie } & 0.062 & 0.081 & 0.067 & 0.092 & 0.052 & 0.049 \\
\hline & $(0.083)$ & $(0.107)$ & $(0.108)$ & $(0.117)$ & $(0.087)$ & $(0.095)$ \\
\hline \multirow{2}{*}{ Ankober } & 0.089 & 0.049 & 0.069 & 0.052 & 0.046 & 0.022 \\
\hline & $(0.103)$ & $(0.094)$ & $(0.106)$ & $(0.085)$ & $(0.102)$ & $(0.055)$ \\
\hline \multirow{2}{*}{ Debre Birhan } & 0.073 & 0.065 & 0.082 & 0.078 & 0.068 & 0.058 \\
\hline & $(0.114)$ & $(0.099)$ & $(0.106)$ & $(0.105)$ & $(0.122)$ & $(0.088)$ \\
\hline \multirow{2}{*}{ Enemayi } & 0.062 & 0.084 & 0.072 & 0.069 & 0.046 & 0.059 \\
\hline & $(0.094)$ & $(0.098)$ & $(0.091)$ & $(0.088)$ & $(0.088)$ & $(0.086)$ \\
\hline \multirow{2}{*}{ Bugena } & 0.086 & 0.089 & 0.063 & 0.075 & 0.053 & 0.041 \\
\hline & $(0.115)$ & $(0.118)$ & $(0.099)$ & $(0.128)$ & $(0.099)$ & $(0.115)$ \\
\hline \multirow{2}{*}{ Adaa } & 0.050 & 0.055 & 0.075 & 0.042 & 0.058 & 0.046 \\
\hline & $(0.075)$ & $(0.082)$ & $(0.084)$ & $(0.061)$ & $(0.079)$ & $(0.084)$ \\
\hline \multirow{2}{*}{ Kersa } & 0.090 & 0.075 & 0.073 & 0.072 & 0.056 & 0.043 \\
\hline & $(0.100)$ & $(0.094)$ & $(0.088)$ & $(0.115)$ & $(0.076)$ & $(0.105)$ \\
\hline \multirow{2}{*}{ Dodota } & 0.067 & 0.061 & 0.097 & 0.080 & 0.079 & 0.043 \\
\hline & $(0.089)$ & $(0.086)$ & $(0.112)$ & $(0.107)$ & $(0.122)$ & $(0.077)$ \\
\hline \multirow{2}{*}{ Shashemene } & 0.058 & 0.055 & 0.086 & 0.068 & 0.075 & 0.054 \\
\hline & $(0.090)$ & $(0.080)$ & $(0.110)$ & $(0.099)$ & $(0.118)$ & (0.089) \\
\hline \multirow{2}{*}{ Cheha } & 0.065 & 0.048 & 0.087 & 0.092 & 0.057 & 0.073 \\
\hline & $(0.099)$ & $(0.079)$ & $(0.101)$ & $(0.137)$ & $(0.113)$ & $(0.105)$ \\
\hline \multirow{2}{*}{ Kedida Gamela } & 0.053 & 0.064 & 0.081 & 0.074 & 0.074 & 0.062 \\
\hline & $(0.084)$ & $(0.083)$ & $(0.110)$ & $(0.091)$ & $(0.103)$ & $(0.077)$ \\
\hline \multirow{2}{*}{ Bule } & 0.093 & 0.078 & 0.089 & 0.096 & 0.067 & 0.025 \\
\hline & $(0.103)$ & $(0.089)$ & $(0.108)$ & $(0.129)$ & (0.097) & $(0.055)$ \\
\hline \multirow{2}{*}{ Boloso } & 0.076 & 0.078 & 0.100 & 0.076 & 0.081 & 0.061 \\
\hline & $(0.097)$ & $(0.142)$ & $(0.158)$ & $(0.131)$ & $(0.118)$ & $(0.089)$ \\
\hline \multirow{2}{*}{ Daramalo } & 0.062 & 0.068 & 0.082 & 0.099 & 0.082 & 0.061 \\
\hline & $(0.104)$ & $(0.092)$ & $(0.124)$ & $(0.129)$ & $(0.161)$ & $(0.094)$ \\
\hline \multirow{2}{*}{ Total } & 0.070 & 0.067 & 0.082 & 0.077 & 0.066 & 0.051 \\
\hline & $(0.099)$ & $(0.097)$ & $(0.111)$ & $(0.111)$ & $(0.111)$ & $(0.090)$ \\
\hline
\end{tabular}

Source: Author's Calculation based on ERHS data. Note: Values in bracket are Standard Deviations. 
Ethiopian Journal of Economics, Volume XVI, No 2, October 2007

Table 5: Availability of school and distance to the nearest town with high school: 2004

\begin{tabular}{|c|c|c|c|c|c|c|c|c|c|c|}
\hline \multirow[b]{2}{*}{ Region } & \multirow[b]{2}{*}{ Wereda } & \multirow[b]{2}{*}{$\begin{array}{c}\text { Peasant } \\
\text { Association }\end{array}$} & \multicolumn{4}{|c|}{1997} & \multicolumn{4}{|c|}{2004} \\
\hline & & & $\begin{array}{l}\text { Primary } \\
\text { school }\end{array}$ & $\begin{array}{l}\text { Junior } \\
\text { School }\end{array}$ & $\begin{array}{l}\text { Secondary } \\
\text { School }\end{array}$ & $\begin{array}{l}\text { Distance to the } \\
\text { Nearest High } \\
\text { School (km) }\end{array}$ & $\begin{array}{l}\text { Primary } \\
\text { school }\end{array}$ & $\begin{array}{l}\text { Junior } \\
\text { School }\end{array}$ & $\begin{array}{c}\text { Secondary } \\
\text { School }\end{array}$ & $\begin{array}{l}\text { Distance to the } \\
\text { Nearest High } \\
\text { School (km) }\end{array}$ \\
\hline \multirow{2}{*}{ Tigray } & Sebha Selassie & Geblen & Yes & No & No & 18 & Yes & No & No & 19 \\
\hline & Ankober & Dinki & No & No & No & $?$ & Yes & No & No & $?$ \\
\hline \multirow{2}{*}{ Amhara } & Debre Birhan & Debrebirhan & Yes & No & No & 10 & Yes & No & No & 5 \\
\hline & Ad'a & Sirbana Goditi & No & Yes & No & 15 & Yes & Yes & No & 10 \\
\hline \multirow{5}{*}{ Oromia } & Kersa & Adel Keye & Yes & No & No & 7 & Yes & No & No & 8 \\
\hline & Dodota & Koro Degaga & Yes & No & No & 25 & Yes & No & No & 15 \\
\hline & Shashemene & Tirurife Ketchema & Yes & Yes & Yes & 2 & Yes & Yes & Yes & 0 \\
\hline & Cheha & Imdibir & No & No & No & 4 & Yes & Yes & Yes & 4 \\
\hline & Kedida Gamela & Aze Adebo & Yes & No & No & 5 & Yes & Yes & No & $?$ \\
\hline
\end{tabular}

Source: Author's computation from ERHS community data 
Andinet Delelegn: Intra-household gender-bias in child educational..

Table 6: Random effects probit and autoregressive estimates

\begin{tabular}{|c|c|c|c|c|c|c|c|c|}
\hline \multirow{4}{*}{ Variables } & \multicolumn{4}{|c|}{ Whole Sample } & \multicolumn{4}{|c|}{ Samples in Tigray Region } \\
\hline & \multicolumn{2}{|c|}{ [1] } & \multicolumn{2}{|c|}{ [2] } & \multicolumn{2}{|c|}{ [3] } & \multicolumn{2}{|c|}{ [4] } \\
\hline & \multicolumn{2}{|c|}{$\begin{array}{c}\text { Marginal Effects after RE Probit } \\
\text { Estimation }\end{array}$} & \multicolumn{2}{|c|}{$\begin{array}{l}\text { Linear Autoregressive Model } \\
\text { (AR(1)) }\end{array}$} & \multicolumn{2}{|c|}{$\begin{array}{c}\text { Marginal Effexts after RE Probit } \\
\text { Estimation }\end{array}$} & \multicolumn{2}{|c|}{$\begin{array}{l}\text { Linear Autoregressive Model } \\
\text { (AR(1)) }\end{array}$} \\
\hline & Coef. & $z$-value & Coef. & z-value & Coef. & z-value & Coef. & z-value \\
\hline Constant & $-2.5904^{\star * \star}$ & 4.9 & $4.0944^{* \star *}$ & 7.98 & $-4.249^{\star \star *}$ & -2.04 & 2.4443 & -1.02 \\
\hline \multicolumn{9}{|c|}{ Household Age-sex group ratio } \\
\hline Male_below 4 & $-0.3481^{* \star *}$ & 2.7 & -0.641671 & 1.26 & $0.077^{* * *}$ & 0.26 & -1.2138 & 0.79 \\
\hline Female_below 4 & -0.1639 & 1.3 & 0.0466068 & 0.1 & $-0.075^{\star \star *}$ & 0.23 & 1.0336 & 0.51 \\
\hline Male_5-9 & $0.2017^{\star *}$ & 2.03 & 0.2845792 & 0.86 & 0.0673 & 0.28 & -1.5204 & 1.29 \\
\hline Female_5-9 & 0.0195 & 0.2 & 0.0060587 & 0.02 & 0.1133 & 0.54 & $-2.4023^{* *}$ & 2.09 \\
\hline Male_10-14 & $0.6068^{* * *}$ & 6.6 & $0.5176797^{*}$ & 1.85 & $0.599^{* * *}$ & 2.47 & -0.3688 & 0.33 \\
\hline Female_10-14 & $0.4799^{* * *}$ & 5.51 & $0.834276^{* * *}$ & 3.11 & $0.824^{\star * *}$ & 3.55 & -0.3573 & 0.37 \\
\hline Male_15-19 & $0.3504^{* * *}$ & 4.1 & $0.5807817^{\star *}$ & 2.03 & 0.6172 & 2.53 & -0.7495 & 0.64 \\
\hline Female_15-19 & $0.1535^{*}$ & 1.76 & $0.7048582^{\star *}$ & 2.17 & 0.6433 & 2.68 & 0.0928 & 0.08 \\
\hline Male_20-24 & -0.0091 & 0.1 & -0.1307145 & 0.37 & -0.0031 & 0.01 & 0.1086 & 0.09 \\
\hline Female_20-24 & $-0.2782^{* * *}$ & 2.7 & 0.1796455 & 0.44 & -0.0639 & 0.22 & -0.9389 & 0.62 \\
\hline Male_25-60 & $0.1323^{*}$ & 1.6 & -0.2242455 & 0.77 & 0.0328 & 0.13 & -0.0926 & 0.08 \\
\hline Female_25-60 & 0.0182 & 0.22 & $-0.5816122^{*}$ & 1.93 & -0.0673 & 0.26 & 0.8763 & 0.61 \\
\hline
\end{tabular}


Ethiopian Journal of Economics, Volume XVI, No 2, October 2007

Table 6 continued...

\begin{tabular}{|c|c|c|c|c|c|c|c|c|}
\hline \multicolumn{9}{|c|}{ Household Characteristics } \\
\hline Head_sex* & -0.0206 & 0.8 & $-0.180022^{* *}$ & 2.11 & 0.0454 & 0.71 & -0.0775 & 0.28 \\
\hline Head_age & 0.0049 & 1.47 & 0.0133734 & 1.21 & 0.0032 & 0.36 & 0.0481 & 0.93 \\
\hline Head_agesqr & -0.0001 & 1.2 & -0.0001287 & 1.31 & -0.0001 & 0.7 & -0.0006 & 1.13 \\
\hline Head_primedu* & $0.1118^{\star * *}$ & 3.82 & 0.0116446 & 0.15 & 0.0449 & 0.8 & 0.0418 & 0.11 \\
\hline Head_junedu* & $0.1708^{\star * *}$ & 2.59 & 0.0261754 & 0.16 & & & & \\
\hline Head_secedu* & 0.0909 & 1.33 & -0.0511498 & 0.26 & & & & \\
\hline Head_teredu* & $0.2863^{* *}$ & 2.18 & $0.6051018^{*}$ & 1.71 & & & & \\
\hline In of hh size & $0.3199^{\star * *}$ & 3.57 & -0.4631516 & 1.36 & 0.2123 & 0.85 & $-2.2137^{*}$ & 1.86 \\
\hline In of hh size sqr & $-0.0433^{*}$ & 1.7 & 0.0973039 & 1.05 & 0.0162 & 0.21 & $0.5578^{* *}$ & 2 \\
\hline Household_mean age & -0.0037 & 1.3 & -0.0021751 & 0.2 & -0.0079 & 1.27 & 0.0138 & 0.44 \\
\hline \multicolumn{9}{|c|}{ Household Asset } \\
\hline landXox & $-0.0043^{*}$ & 1.8 & $0.0161301^{* *}$ & 1.96 & -0.0331 & 0.73 & -0.0441 & 0.26 \\
\hline landXlivskt & 0.0004 & 1.35 & 0.001195 & 1.18 & -0.0002 & 0.03 & $-0.0551^{*}$ & 1.64 \\
\hline land & -0.0059 & 0.6 & -0.0264461 & 0.7 & $-0.197^{\star * *}$ & 1.44 & 0.9413 & 1.55 \\
\hline livstk_no & -0.0024 & 1.2 & -0.0084601 & 1.31 & 0.0018 & 0.28 & 0.0322 & 1.04 \\
\hline oxen_no & 0.0171 & 1.47 & -0.0282252 & 0.79 & $0.047^{\star \star *}$ & 0.85 & -0.1328 & 0.58 \\
\hline
\end{tabular}


Andinet Delelegn: Intra-household gender-bias in child educational..

Table 6 continued...

\begin{tabular}{|c|c|c|c|c|c|c|c|c|}
\hline \multicolumn{9}{|c|}{ Household Welfare level } \\
\hline Incons_lg & 0.0155 & 1.55 & $0.104056^{* * *}$ & 3.15 & 0.0474 & 2.01 & $0.2575^{\star * *}$ & 2.84 \\
\hline GPE (Generalized Probit error) & -0.0444 & 1.3 & & & 0.0407 & 0.51 & - & - \\
\hline Rho & & 0.2 & & & $0.1917^{*}$ & & & \\
\hline sigma_u & & 0.49 & & & 0.4871 & & & \\
\hline /lnsig2u & & 1.4 & & & -1.4388 & & & \\
\hline number of obs. & & 4897 & & 1786 & 545 & & 173 & \\
\hline Loglikelihood & & -2383.52 & & & -202.598 & & & \\
\hline Wald Chisquare & & $958.56^{*}$ & & 606.66 & 101.65 & & $314.34^{*}$ & \\
\hline R-squared - Within & & & & 0.21 & & & 0.6459 & \\
\hline - Between & & & & 0.3 & & & 0.4112 & \\
\hline - Overall & & & & 0.27 & & & 0.5651 & \\
\hline rho_ar (estimated autocorrelation & & & & 0.31 & & & 0.4319 & \\
\hline sigma_u & & & & - & & & 0 & \\
\hline sigma_e & & & & 1.05 & & & 0.8658 & \\
\hline rho_fov (fraction of variance due to $u_{-} \mathrm{i}$ ) & & & & - & & & 0 & \\
\hline
\end{tabular}

Note: Reported constants are from the main regression result coefficients (not the marginal effects). ${ }^{* *}=$ Significant at $1 \%$, ${ }^{* *}=$ Significant at $5 \%$ and ${ }^{*}=$ Significant at $10 \%$. Over time mean and Change of time varying household level variables are included in the regression but not reported here and they are available at request from the author Village by round dummies interaction terms are included in the regression and most of these terms are statistically significant. However, the coefficients are not reported here. Coefficients on education are dropped due to co linearity in Tigray and Amhara region. 
Ethiopian Journal of Economics, Volume XVI, No 2, October 2007

\begin{tabular}{|c|c|c|c|c|c|c|c|c|}
\hline \multirow{4}{*}{ Variables } & \multicolumn{4}{|c|}{ Samples in Amhara Region } & \multicolumn{4}{|c|}{ Samples in Oromia Region } \\
\hline & \multirow{2}{*}{\multicolumn{2}{|c|}{$\begin{array}{c}\text { Marginal Effexts after RE Probit } \\
\text { Estimation }\end{array}$}} & & & & & & \\
\hline & & & \multicolumn{2}{|c|}{$\begin{array}{c}\text { Linear Autoregressive Model } \\
(\operatorname{AR}(1))\end{array}$} & \multicolumn{2}{|c|}{$\begin{array}{c}\text { Marginal Effexts after RE Probit } \\
\text { Estimation } \\
\end{array}$} & \multicolumn{2}{|c|}{$\begin{array}{l}\text { Linear Autoregressive Model } \\
\text { (AR(1)) }\end{array}$} \\
\hline & Coef. & z-value & Coef. & z-value & Coef. & z-value & Coef. & z-value \\
\hline Constant & $-3.11^{* * *}$ & 2.89 & 1.7489 & 1.23 & -1.2569 & 1.2 & $4.9621^{* * *}$ & 4.17 \\
\hline \multicolumn{9}{|c|}{ Household Age-sex group ratio } \\
\hline Male_below 4 & $-0.87^{* * *}$ & 5.21 & -1.3622 & 1.24 & -0.4432 & 1.57 & -0.34088 & 0.36 \\
\hline Female_below 4 & $-0.91^{* * *}$ & 5.13 & -0.8584 & 0.79 & $-0.5326^{*}$ & 1.97 & -0.28585 & 0.31 \\
\hline Male_5-9 & -0.0014 & 0.01 & -0.189 & 0.29 & $0.3909^{*}$ & 1.89 & 0.797052 & 1.26 \\
\hline Female_5-9 & 0.0502 & 0.41 & -0.0746 & 0.12 & 0.1347 & 0.61 & 0.489877 & 0.74 \\
\hline Male_10-14 & $0.39^{* * *}$ & 3.14 & $1.2657^{* *}$ & 2.04 & $0.751^{* * *}$ & 3.9 & 0.074034 & 0.14 \\
\hline Female_10-14 & 0.1403 & 1.2 & $0.9963^{*}$ & 1.66 & $0.464^{* * *}$ & 2.55 & $1.31783^{* *}$ & 2.46 \\
\hline Male_15-19 & 0.1201 & 1.14 & -0.3841 & 0.07 & 0.224 & 1.28 & $1.5102^{* * *}$ & 2.93 \\
\hline Female_15-19 & 0.058 & 0.53 & 0.5492 & 0.86 & 0.1283 & 0.7 & 0.11024 & 0.19 \\
\hline Male_20-24 & -0.0406 & 0.3 & 0.4411 & 0.56 & -0.0803 & 0.41 & $1.10906^{*}$ & 1.8 \\
\hline Female_20-24 & -0.0727 & 0.49 & -0.5428 & 0.66 & -0.1855 & 0.85 & 0.823557 & 1.13 \\
\hline Male_25-60 & -0.0523 & 0.4 & 0.3211 & 0.43 & $0.3351^{* *}$ & 2.06 & -0.02867 & 0.06 \\
\hline Female_25-60 & 0.1644 & 1.51 & -0.4424 & 0.67 & 0.0203 & 0.11 & 0.130802 & 0.24 \\
\hline
\end{tabular}


Andinet Delelegn: Intra-household gender-bias in child educational...

\begin{tabular}{|c|c|c|c|c|c|c|c|c|}
\hline \multicolumn{9}{|c|}{ Household Characteristics } \\
\hline Head_sex* & -0.0368 & 0.89 & $-0.3852^{* *}$ & 2.07 & 0.015 & 0.31 & $-0.2324^{*}$ & 1.74 \\
\hline Head_age & $0.013^{\star *}$ & 2.3 & 0.0078 & 0.26 & -0.0016 & 0.19 & -0.01702 & 0.69 \\
\hline Head_agesqr & $-0.001^{* *}$ & 2.36 & -0.0001 & 0.31 & 0.00001 & 0.17 & 0.000236 & 1.02 \\
\hline Head_primedu* & $0.099^{* *}$ & 2.2 & $0.2705^{* *}$ & 1.6 & 0.0315 & 0.57 & -0.03449 & 0.24 \\
\hline Head_junedu* & 0.1225 & 0.98 & -0.1548 & 0.32 & 0.2159 & 1.55 & 0.273903 & 0.96 \\
\hline Head_secedu* & & - & - & & -0.0744 & 0.72 & $0.58932^{*}$ & 1.74 \\
\hline Head_teredu* & & - & - & & 0.2592 & 1.04 & 0.440635 & 0.64 \\
\hline In of hh size & $0.2873^{* *}$ & 2.27 & -0.4396 & 0.59 & $0.347^{* * *}$ & 1.95 & $-1.0738^{*}$ & 1.71 \\
\hline In of hh size sqr & -0.0592 & 1.44 & 0.1696 & 0.76 & -0.0327 & 0.64 & 0.245212 & 1.56 \\
\hline Household_mean age & $0.009^{* *}$ & 2.37 & -0.0025 & 0.11 & $-0.01^{* * *}$ & 1.88 & -0.01142 & 0.6 \\
\hline \multicolumn{9}{|c|}{ Household Asset } \\
\hline landXox & -0.002 & 0.86 & 0.0017 & 0.12 & $-0.02^{* * *}$ & 3.2 & $0.03974^{* *}$ & 2.01 \\
\hline landXlivskt & $0.0006^{*}$ & 1.75 & $0.0030^{* *}$ & 1.97 & 0.0012 & 1.52 & -0.00122 & 0.68 \\
\hline land & $-0.0197^{*}$ & 1.73 & -0.0494 & 0.94 & $0.0304^{*}$ & 1.63 & -0.01635 & 0.21 \\
\hline livstk_no & $-0.0039^{*}$ & 1.93 & $-0.0188^{* *}$ & 1.96 & -0.0004 & 0.1 & 0.014336 & 1.22 \\
\hline oxen_no & $0.0305^{* *}$ & 2.36 & 0.0494 & 0.99 & $0.0562^{*}$ & 1.87 & $-0.235^{\star * *}$ & 2.69 \\
\hline
\end{tabular}


Ethiopian Journal of Economics, Volume XVI, No 2, October 2007

\begin{tabular}{|c|c|c|c|c|c|c|c|c|}
\hline \multicolumn{9}{|c|}{ Household Welfare level } \\
\hline Incons_lg & -0.0218 & 1.34 & $0.1584^{\star *}$ & 2.35 & 0.0019 & 0.1 & -0.02025 & 0.05 \\
\hline GPE (Generalized Probit error) & 0.0381 & 0.84 & & & -0.106 & 1.59 & & \\
\hline Rho & & $0.2306^{*}$ & & & $0.1519^{*}$ & & & \\
\hline sigma_u & 0.55 & & & & 0.4232 & & & \\
\hline /Insig2u & -1.2 & & & & -1.7198 & & & \\
\hline number of obs. & 1674 & & 499 & & 1343 & & & 554 \\
\hline Loglikelihood & -717.77 & & & & -608.105 & & & \\
\hline Wald Chisquare & $271.77^{*}$ & & $100.53^{*}$ & & $298.55^{*}$ & & & 97.22 \\
\hline R-squared - Within & & & 0.1757 & & & & & 0.1003 \\
\hline - Between & & & 0.1708 & & & & & 0.2396 \\
\hline \multirow[t]{2}{*}{ - Overall } & & & 0.179 & & & & & 0.1727 \\
\hline & & & 0.217 & & & & & 0.2487 \\
\hline sigma_u & & & 0 & & & & & 0 \\
\hline \multirow[t]{2}{*}{ sigma_e } & & & 1.0766 & & & & & 1.0527 \\
\hline & & & 0 & & & & & 0 \\
\hline
\end{tabular}


Andinet Delelegn: Intra-household gender-bias in child educational...

Table 6 Random ..., cont'd

\begin{tabular}{|c|c|c|c|c|}
\hline \multirow{4}{*}{ Variables } & \multicolumn{4}{|c|}{ Samples in SNNP } \\
\hline & \multicolumn{2}{|c|}{ [9] } & \multicolumn{2}{|c|}{ [10] } \\
\hline & \multicolumn{2}{|c|}{ Marginal Effexts after RE Probit } & \multicolumn{2}{|c|}{ Marginal Coefficients from Linear } \\
\hline & Coef. & z-value & Coef. & z-value \\
\hline Constant & -1.7185 & 1.5 & $3.579831^{* \star *}$ & 3.9 \\
\hline \multicolumn{5}{|c|}{ Household Age-sex aroup ratio } \\
\hline Male_below 4 & -0.418 & 1.35 & $-1.663432^{*}$ & 1.64 \\
\hline Female_below 4 & 0.3605 & 1.3 & $-1.414165^{*}$ & 1.67 \\
\hline Male_5-9 & $0.5332^{* *}$ & 2.34 & 0.4818685 & 0.76 \\
\hline Female_5-9 & 0.1542 & 0.64 & -0.0409092 & 0.06 \\
\hline Male_10-14 & $0.786^{* * *}$ & 3.98 & 0.5448037 & 1.03 \\
\hline Female_10-14 & $0.629 * * *$ & 3.31 & 0.3615266 & 0.75 \\
\hline Male_15-19 & 0.89 & 4.12 & 0.6904884 & 1.25 \\
\hline Female_15-19 & $0.3924^{*}$ & 1.79 & 0.3104279 & 0.46 \\
\hline Male_20-24 & $-0.3792^{*}$ & 1.77 & -0.9416805 & 1.43 \\
\hline Female_20-24 & $-0.4314^{*}$ & 1.89 & 0.568111 & 0.72 \\
\hline Male_25-60 & 0.0625 & 0.32 & -0.0738633 & 0.14 \\
\hline Female_25-60 & -0.1875 & 1.03 & -0.0612614 & 0.12 \\
\hline \multicolumn{5}{|c|}{ Household Characteristics } \\
\hline Head_sex* & 0.0209 & 0.32 & -0.0703695 & 0.39 \\
\hline Head_age & -0.0099 & 1.15 & 0.0129079 & 0.73 \\
\hline Head_agesqr & 0.0001 & 1.55 & -0.0000709 & 0.5 \\
\hline Head_primedu* & $0.0986^{*}$ & 1.88 & -0.0128374 & 0.1 \\
\hline Head_junedu* & 0.0632 & 0.66 & -0.0713425 & 0.29 \\
\hline Head_secedu* & 0.1408 & 1.3 & -0.1549146 & 0.6 \\
\hline Head_teredu* & $0.3892^{* *}$ & 2.16 & 0.2540834 & 0.59 \\
\hline In of hh size & $0.3495^{*}$ & 1.69 & 0.4165212 & 0.67 \\
\hline In of hh size sqr & -0.0369 & 0.6 & -0.1475452 & 0.85 \\
\hline Household_mean age & 0.0032 & 0.42 & -0.0044824 & 0.2 \\
\hline \multicolumn{5}{|c|}{ Household Asset } \\
\hline landXox & 0.0223 & 1.17 & -0.0055352 & 0.15 \\
\hline landXlivskt & 0.0016 & 0.4 & $0.0211251^{* *}$ & 2.27 \\
\hline land & -0.0331 & 1.06 & -0.0833169 & 0.9 \\
\hline livstk_no & 0.0062 & 0.53 & -0.0349553 & 1.21 \\
\hline oxen_no & 0.0296 & 0.55 & -0.0240563 & 0.19 \\
\hline \multicolumn{5}{|c|}{ Household Welfare level } \\
\hline Incons_lg & $0.0461^{*}$ & 1.87 & $0.1267691^{*}$ & 1.83 \\
\hline GPE (Generalized Probit & -0.0829 & 1.11 & & \\
\hline Rho & 0.16 & & & \\
\hline sigma_u & 0.43 & & & \\
\hline /Insig2u & -1.67 & & & \\
\hline number of obs. & 1335 & & & 560 \\
\hline Loglikelihood & -552.73 & & & \\
\hline Wald Chisquare & $310.26^{*}$ & & & 70.13 \\
\hline R-squared - Within & & & & 0.11 \\
\hline - Between & & & & 0.1 \\
\hline \multirow[t]{2}{*}{ - Overall } & & & & 0.11 \\
\hline & & & & 0.41 \\
\hline sigma_u & & & & - \\
\hline sigma_e & & & & 1.09 \\
\hline
\end{tabular}


Table 7: Wald-test results on HO: The marginal effects of coefficients for male and female are statistically equal

Marginal Effects after Linear Autoregressive MarginalEffectsafter LinearAutoregressive

Age RE Probit Estimation Model (AR(1)) RE Probit Estimation Model (AR(1))

\begin{tabular}{|c|c|c|c|c|c|c|c|c|}
\hline \multirow{3}{*}{ Categories } & \multirow{2}{*}{\multicolumn{4}{|c|}{ Whole Sample }} & \multirow{2}{*}{\multicolumn{4}{|c|}{ Samples in Tigray Region }} \\
\hline & & & & & & & & \\
\hline & Chisqrd & $p$-value & Chisqrd & $p$-value & Chisqrd & p-value & Chisqrd & p-value \\
\hline Age 5-9 & 2.3 & 0.13 & 0.16 & 0.69 & 0.03 & -0.86 & 0.57 & -0.45 \\
\hline Age $10-14$ & 1.23 & 0.27 & 0.69 & 0.41 & 0.66 & -0.42 & 0 & -0.99 \\
\hline \multirow[t]{3}{*}{ Age $15-19$} & $2.97^{*}$ & 0.08 & 0.51 & 0.48 & 0.01 & -0.93 & 0.32 & -0.57 \\
\hline & \multicolumn{4}{|c|}{ Samples in Amhara Region } & \multicolumn{4}{|c|}{ Samples in Oromia Region } \\
\hline & Chisqrd & p-value & Chisqrd & p-value & Chisqrd & p-value & Chisqrd & $p$-value \\
\hline Age 5-9 & 0.1 & 0.75 & 0.03 & 0.87 & 0.94 & -0.33 & 0.14 & -0.7 \\
\hline Age 10-14 & $2.99^{*}$ & 0.08 & 0.15 & 0.7 & 1.38 & -0.24 & $3.14^{*}$ & -0.08 \\
\hline \multirow[t]{3}{*}{ Age 15-19 } & 0.2 & 0.66 & 0.65 & -0.42 & 0.16 & -0.69 & $3.56^{*}$ & -0.06 \\
\hline & \multicolumn{4}{|c|}{ Samples in SNNP } & & & & \\
\hline & Chisqrd & p-value & Chisqrd & p-value & & & & \\
\hline Age 5-9 & 1.99 & 0.16 & 0.46 & -0.5 & & & & \\
\hline Age 10-14 & 0.39 & 0.53 & 0.08 & -0.78 & & & & \\
\hline Age $15-19$ & $3.31^{*}$ & 0.07 & 0.26 & -0.61 & & & & \\
\hline
\end{tabular}

Note: ${ }^{* *}=$ Significant at $1 \%,{ }^{* *}=$ Significant at $5 \%$ and ${ }^{*}=$ Significant at $10 \%$ 


\section{Figure 1: Kernel Density of educational spending}

1. Unconditional educ share

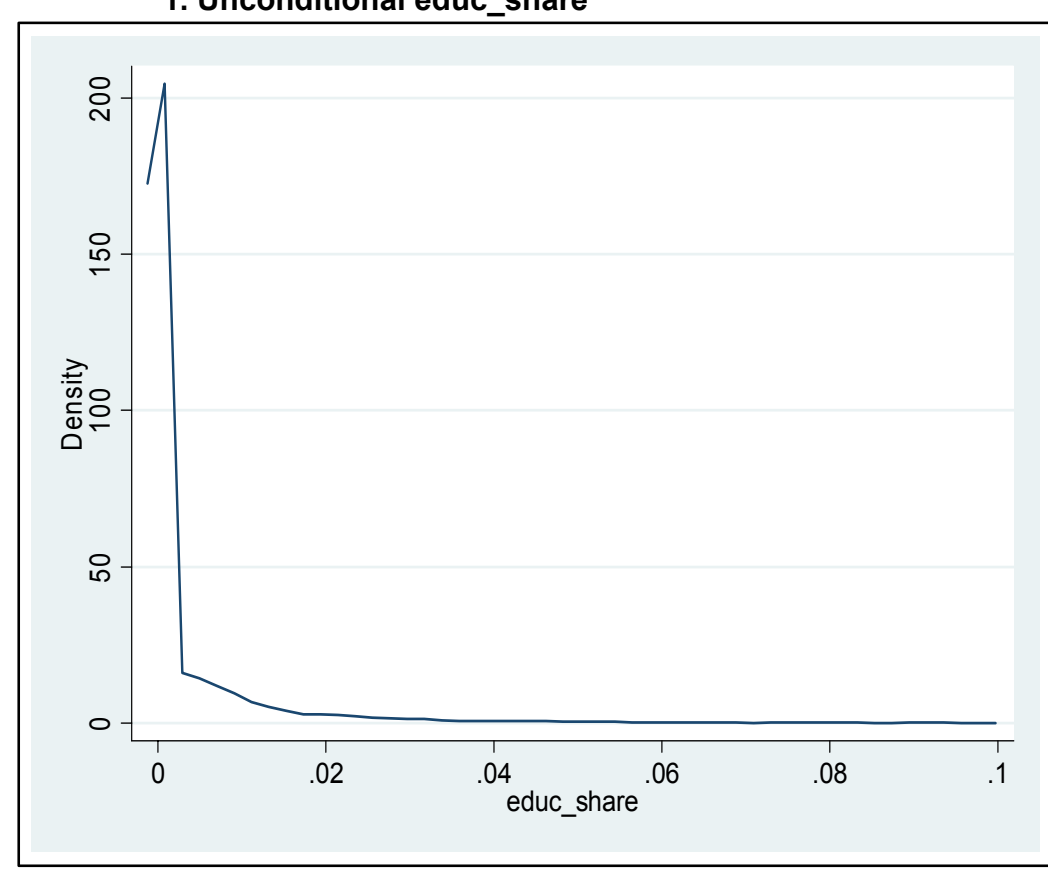

2. Conditional educ share

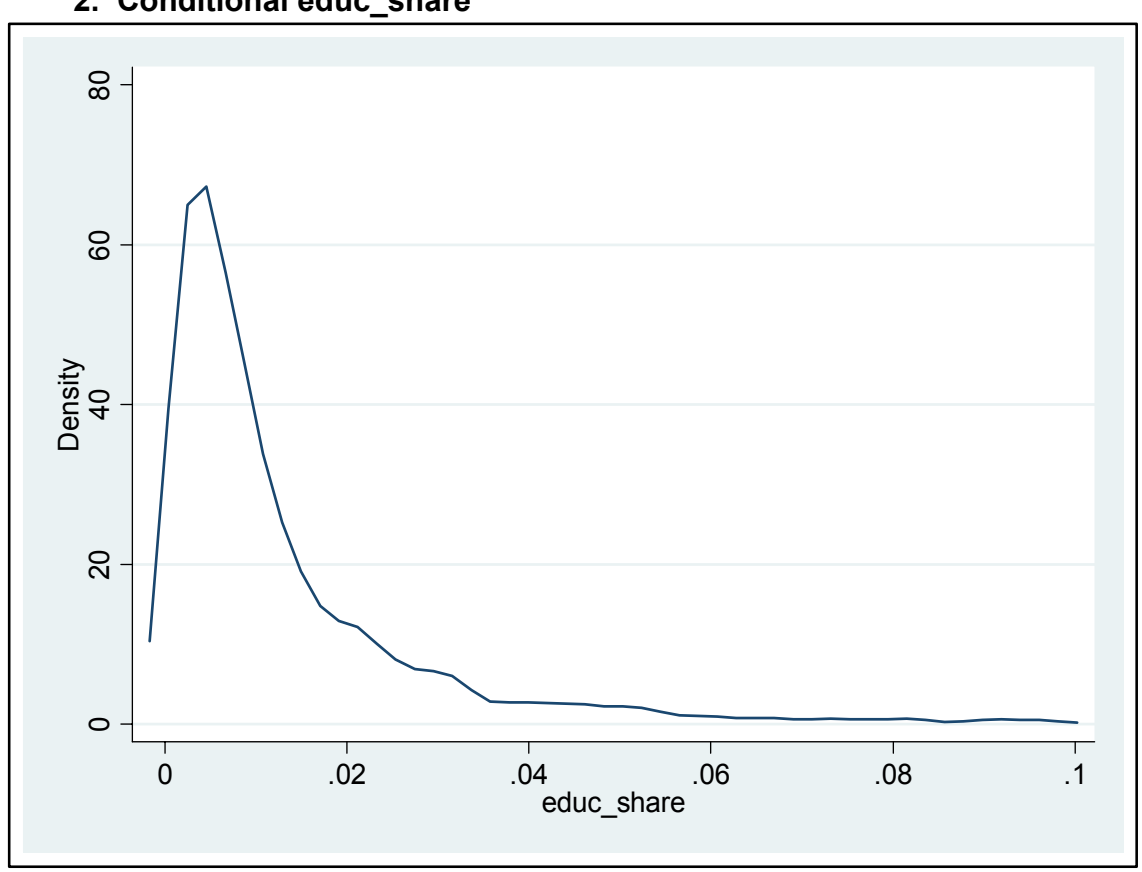




\section{Unconditional Ineshare}

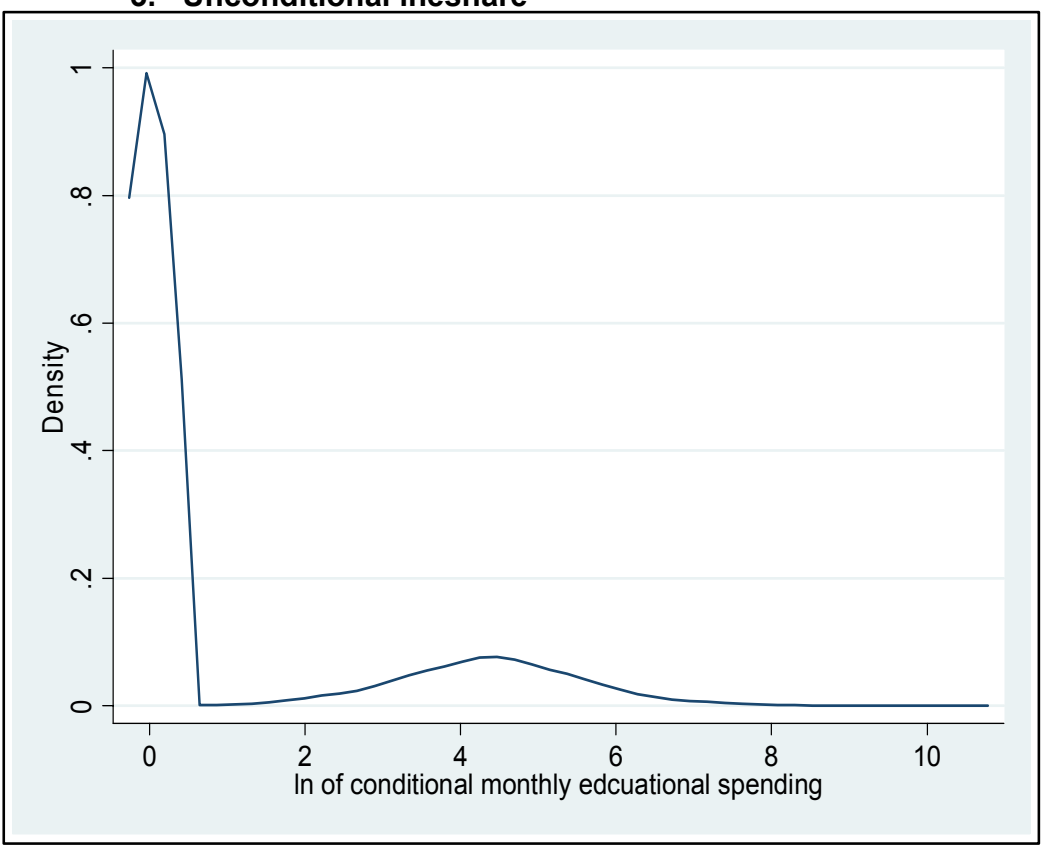

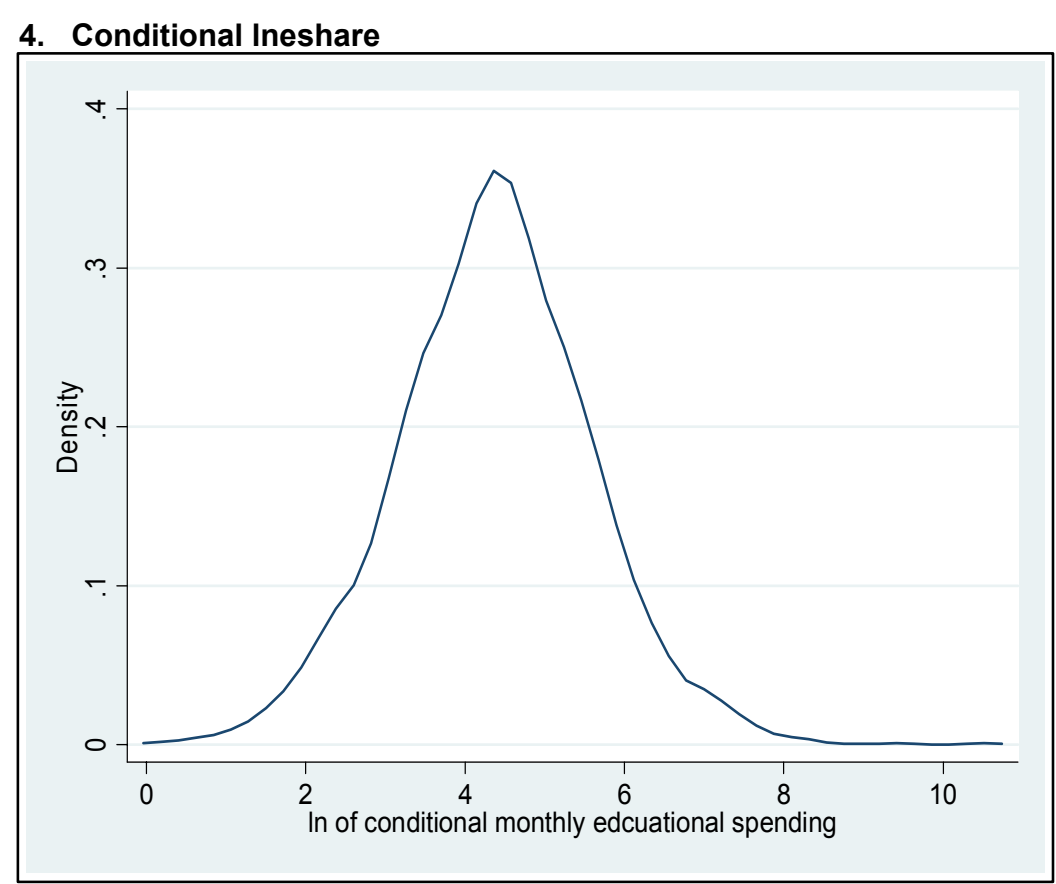


